\title{
Effect of Fly Ash Height in the Adsorption Column to Remove Phosphate in Laundry Wastewater
}

\author{
Hafidya Norista Pramesti, Wisnu Setyabudi, Euis Nurul Hidayah *, \\ Okik Hendriyanto Cahyonugroho, Yayok Suryo Purnomo
}

Department of Environmental Engineering, Universitas Pembangunan Nasional “Veteran” Surabaya, East Java, Indonesia

*Corresponding author:

E-mail: euisnh.tl@upnjatim.ac.id.

\begin{abstract}
Laundry wastewater is one of the contributors to domestic wastewater since laundry services have been increasing in urban living, especially in big cities. Laundry wastewater may contain phosphate compounds, and the concentration should be reduced before discharge into water bodies. One of the easiest and friendly methods for removing phosphate in laundry wastewater is by using the adsorption process. Adsorption is influenced by the adsorbent material, and fly ash has been implemented as adsorbent due to its high capacity to adsorb pollutants. This study aims to observe the effect of adsorbent height in the column and the effect of flow rate to treat phosphate in laundry wastewater. This study applied Thomas modeling to determine the model for fly ash capacity as adsorbent. The results showed that the highest flow rate, $15 \mathrm{~mL} / \mathrm{min}$, and the highest fly ash height $20 \mathrm{~cm}$ gave the optimum removal of phosphate, about 98.63-99.22\%. Besides, Thomas model obtained the value of the linear regression coefficient $R^{2}$ of 0.5415
\end{abstract}

Keywords: Phospate, adsorption, fly ash adsorbent

\section{Introduction}

Detergent and soap from the laundry home industries had given an environmental issue. This is because laundry wastewater contains phosphate, especially from detergent. Detergents get more attention because of used more often than soap. Detergents have a better capability in hard water than soap. The increasing number of laundry industries resulted in increasing detergent and increasing the phosphates concentration eventually (Stevens et al., 2011; Maharani, 2018). Sodium tri poly-phosphate has been known as a builder and surfactant, which contains phosphate. Another environmental issue is waste from coal combustion, which is well known as fly ash. Fly ash is the leftover product, it is generated from large industries, such as the cement industry, PLTU, railroad industry, and others. Accumulation of fly ash is not comparable with the management of fly ash handling. Most of the generated fly ash has been ended in the landfill or just discharged to the existing land. One of the environmental technologies for pollution handling is using adsorption (Anggia \& Suprapto, 2016; Slamet \& Karina, 2017). There are two different ways to carry adsorption processes, that is in the batches and the column system. The batches system is the adsorbent is mixing in a fixed amount of solution, then the quality of treated water and adsorbent changes at certain intervals time.

Column system is the adsorbent is fixed, and raw water is contacted with the adsorbent in up-flow or down-flow system, then adsorbent can adsorb the pollutant optimally until the condition of the effluent concentration approaches standard quality or the adsorbent become exhausted, which is shown in the breakthrough curve (Kirk \& Othmer, 1981). The column system has greater capacity than the batch system due to the large area contacted and continues flow,

\section{How to cite:}

Pramesti, H. N., Setyabudi, P. S., Hidayah, E. N., Cahyonugroho, O. H., \& Purnomo, Y. S. (2020). Effect of fly ash height in the adsorption column to remove phosphate in laundry wastewater. $1^{\text {st }}$ International Conference Eco. Innovation in Science, Engineering, and Technology. NST Proceedings. pages 47-51. doi:10.11594/ nstp.2020.0506 
and the processes are affected by the volume of adsorbent and the flowrate (Babu \& Gupta, 2005). Mathematical models have been developed to reveal the phenomenon in the system, to determine the constant, to forecast the developing system. (Maharani, 2018) According to the adsorption system, several adsorption models have been developed such as the Thomas model, Adam-Bohard model, Yoon and Nelson model, Clark model, and bed depth service time system model (Voice, 1997). Each model has its advantages and disadvantages, while Thomas is most frequently used for column adsorption for heavy metals. This study aims to observe the effect of adsorbent height in the column and the effect of flow rate to treat phosphate in laundry wastewater and apply the Thomas model to determine the quality of the adsorption process by using fly ash as adsorbent.

\section{Material and Methods}

The experimental study was carried out by using an adsorption column. The cylinder column was made from Flexi-glass with a ratio of length and diameter. Fly ash was filled in the column, Current flow is adjusted as a down-flow system, $5 \mathrm{~mL} / \mathrm{min}, 10 \mathrm{~mL} / \mathrm{min}$, and $15 \mathrm{~mL} / \mathrm{min}$ through the media adsorbent fly ash. Down-flow means raw water was flowing from the top to the bottom of the column. The height of the adsorbent is installed under $10 \mathrm{~cm}, 15 \mathrm{~cm}$, and $20 \mathrm{~cm}$. The sampling tie is taken every 60 minutes for 300 minutes adsorption process, which means that the experiment resulted in 5 samples. Samples were measured for phosphate concentration under different sampling times, the different height of adsorbent, and different flowrate. Thomas's model is applied through considering the initial phosphate concentration $(\mathrm{mg} / \mathrm{L})$, sampling time (minutes), effluent phosphate concentration $(\mathrm{mg} / \mathrm{L})$, flowrate $(\mathrm{mL} / \mathrm{minutes})$, the mass of adsorbent (gram).

\section{Results and Discussion}

\section{Effect of high adsorbent on phosphate removal}

The high adsorbent in the adsorbent column affects phosphate removal.

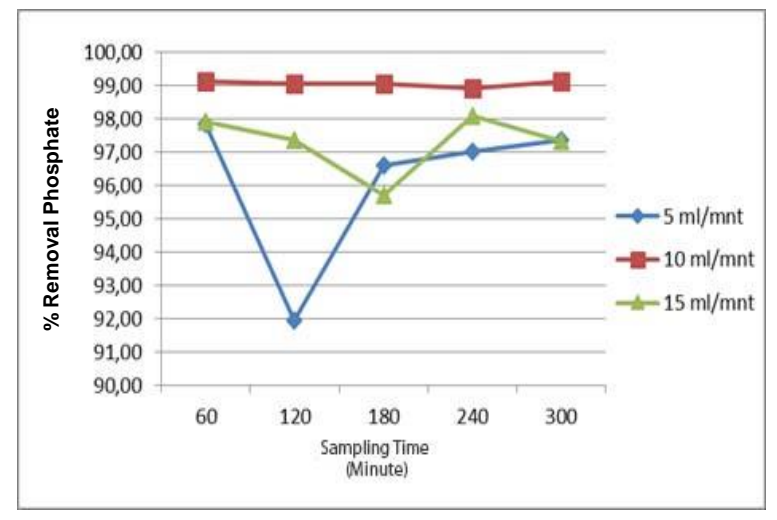

Figure 1. Relations of time sampling with percent allowance in various flow at high adsorbent $10 \mathrm{~cm}$

In the figure 1, it can be seen that the variation of the height of the adsorbent $10 \mathrm{~cm}$ debit 10 $\mathrm{mL} / \mathrm{min}$ shows that the percent allowance is stable compared to the debit 5 and $15 \mathrm{~mL} / \mathrm{min}$ which is equal to $98.9-99.1 \%$, ie at sampling times 60 and 300 minutes is $99.10 \%$ Discharge of $5 \mathrm{~mL} / \mathrm{min}$ despite a decrease in the sampling time of 60 minutes but then an increase in the next minute, this shows that the height of the adsorbent $10 \mathrm{~cm}$ with a flow rate of $5 \mathrm{~mL} / \mathrm{min}$ requires a longer sampling time for maximum results, while at a discharge of $15 \mathrm{~mL} / \mathrm{min}$ shows a graph that tends to decrease even though it had experienced at 240 minutes then decreased at the next minute, it happened because of the low adsorbent height and large discharge, the adsorbent will decrease its effectiveness. 


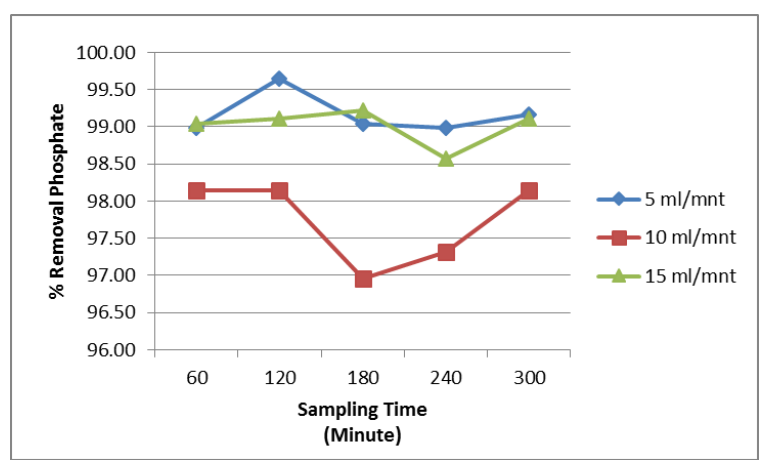

Figure 2. Relations of time sampling with percent allowance in various flow at high adsorbent $15 \mathrm{~cm}$

According to figure 2 , shows that the height of the adsorbent $15 \mathrm{~cm}$ produces a higher percentage of allowance compared to the height of the adsorbent $10 \mathrm{~cm}$, which is set aside approximately $97.3-99.64 \%$, at $5 \mathrm{~mL} / \mathrm{min}$ discharge the peak is at sampling times 60,120 , and 300 minutes amounted to $98.15 \%, 15 \mathrm{~mL} / \mathrm{min}$ discharge at 180 minutes sampling time was $99.10 \%$ and the highest allowance for adsorbent height was $15 \mathrm{~cm}$ at $5 \mathrm{~mL} / \mathrm{min}$ discharge variation 120 minutes sampling time which reached $99.64 \%$

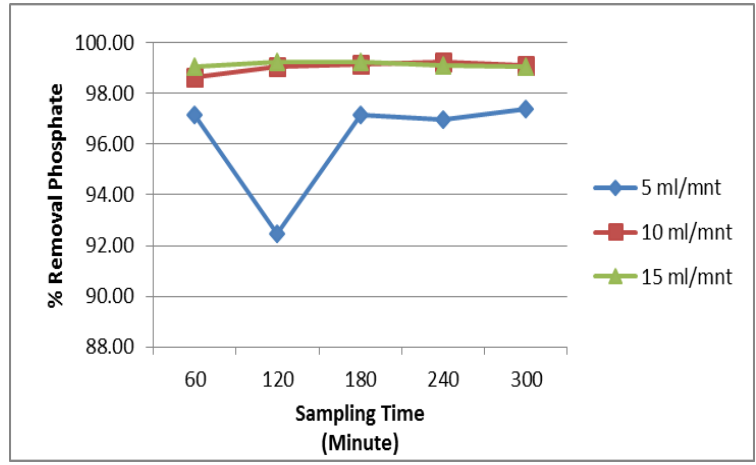

Figure 3. Relations of time sampling with percent allowance in various flow at high adsorbent $20 \mathrm{~cm}$

In the fig.-3 has a higher allowance percentage than in other high variations, the discharge of $10 \mathrm{~mL} / \mathrm{min}$ and $15 \mathrm{~mL} / \mathrm{min}$ percent obtained resulted in a more stable phosphate removal of 98.63-99.22\%, while at $5 \mathrm{~mL} / \mathrm{min}$ discharge had decreased at the beginning of the minutes then continued to increase with increasing time, it happens because the height of the adsorbent is higher and the smaller the discharge it takes longer to get the optimum allowance. The higher or higher volume of adsorbent in the adsorption column causes the amount of adsorbate to be absorbed to be greater and to be saturated longer. This is consistent with previous studies that the higher or the volume of adsorbent used, the more the amount of adsorbate is absorbed (Maharani, 2018). The results showed that several variations of experiments experienced ups and downs of removal which is less stable because there is no control of $\mathrm{pH}$. Humic acid aggression is influenced by strong hydrogen bonds, the repulsion between positive charges occurs, so adsorbates are adsorbed small (Zhang et al., 2011; Tandy et al., 2012) Modification of physical and chemical properties can increase the capacity of fly ash adsorption, activator concentration gives an effect on the activation process that is the higher the activator concentration, the greater the effect to bind impurities out through the pores of the fly ash so that the pore volume is wider. Increased adsorption capacity can make adsorbents from coal fly ash competitive when compared to activated carbon and zeolites (Zhang et al., 2011). Here the phosphate ions will be absorbed by the pores in the adsorbent wall, the fluid will carry contaminants into the bed, away from the inlet, until eventually the entire pores of the adsorbent will be filled with phosphate ions causing the saturation region to increase along increasing time (Benyoucef \& Amrani, 2011). In this study it can be concluded 
that a high flow rate with a low adsorbent height is obtained by decreasing the concentration of phosphate which is less, this is because the contact between the adsorbent with the waste takes place quickly, so the possibility of phosphate absorbed is very small. While the high adsorbent height with a low flow rate will require a longer time to get the optimum phosphate concentration reduction.

\section{Thomas adsorption model}

Column adsorption data is adjusted to the Thomas model by plotting data between $\ln (\mathrm{Co} / \mathrm{Ct})$ over time, then the regression equation is used to determine the kinetic parameters of the Thomas model in the form of rate constants $\left(K_{T H}\right)$ and the maximum concentration of solutes in the phase solid $\left(\mathrm{q}_{\mathrm{TH}}\right)$.

Table 1. Parameters of the Thomas equation model in various experiments

\begin{tabular}{ccccccc}
$\begin{array}{c}\text { Varia- } \\
\text { tion }\end{array}$ & $\begin{array}{c}\mathbf{C o} \\
(\mathbf{m g} / \mathbf{L})\end{array}$ & $\begin{array}{c}\mathbf{Q} \\
(\mathbf{m L} / \mathbf{m i n})\end{array}$ & $\begin{array}{c}\text { Height of } \\
\text { adsorbent } \\
(\mathbf{C m})\end{array}$ & $\begin{array}{c}\boldsymbol{K}_{\boldsymbol{T H}} \\
(\mathbf{m L} / \mathbf{m g} / \mathbf{m i n})\end{array}$ & $\begin{array}{c}\boldsymbol{q}_{\boldsymbol{T H}} \\
(\mathbf{m g} / \mathbf{g})\end{array}$ & $\boldsymbol{R}^{\mathbf{2}}$ \\
\hline 1 & 16,74 & 5 & 10 & 0,065 & 2,56 & 0,0355 \\
2 & 16,74 & 10 & 10 & 0,011 & 44,78 & 0,0287 \\
3 & 16,74 & 15 & 10 & 0,017 & 34,40 & 0,085 \\
4 & 16,74 & 5 & 15 & 0,065 & 2,50 & 0,0538 \\
5 & 16,74 & 10 & 15 & 0,035 & 7,22 & 0,0573 \\
6 & 16,74 & 15 & 15 & 0,035 & 13,12 & 0,0542 \\
7 & 16,74 & 5 & 20 & 0,11 & 0,71 & 0,1515 \\
8 & 16,74 & 10 & 20 & 0,10 & 2,28 & 0,5741 \\
9 & 16,74 & 15 & 20 & 0,01 & 34,40 & 0,0463 \\
\hline
\end{tabular}

Table 1 shows the results of the constant and adsorption capacity of the model equations Thomas. The highest constant can be seen in the variation of $10 \mathrm{~cm}$ adsorbent height at $5 \mathrm{~mL} / \mathrm{min}$ discharge of $0.065 \mathrm{~mL} / \mathrm{mg} /$ minute with an adsorption capacity of $2.56 \mathrm{mg} / \mathrm{g}$. At $15 \mathrm{~cm}$ height the highest constant value at $5 \mathrm{~mL} / \mathrm{min}$ discharge is $0.065 \mathrm{~mL} / \mathrm{mg} / \mathrm{minute}$ with an adsorption capacity of $2.50 \mathrm{mg} / \mathrm{g}$, At $15 \mathrm{~cm}$ high adsorbent the highest constant value at $5 \mathrm{~mL} / \mathrm{min}$ discharge is 0.11 with adsorption capacity $0.71 \mathrm{mg} / \mathrm{g}$. With increasing velocity flow, the constant value decreases inversely with the higher adsorption capacity value, this shows the higher speed increases the driving force of the adsorption process (Voice, 1997; Kirk \& Othmer, 1981). It can also be seen in Table 1 that the constant value of the Thomas model increases with the increase in the height of the adsorbent in the adsorption column, the constant price increase shows that the resistance of mass transfer in the adsorbent layer cannot be ignored in the operating conditions (Watson, 1999). linear in this study the highest Thomas model is 0.5741 . Which means the independent variable can explain the dependent variable variance of $57.41 \%$.

\section{Conclusion}

This study concluded that the highest flow rate, $15 \mathrm{~mL} / \mathrm{min}$, and the highest fly ash height 20 $\mathrm{cm}$ gave the optimum removal of phosphate, about 98.63-99.22\%. It indicates that the highest flow rate and highest adsorbent height caused longer contact time during adsorption, therefore the phosphate removal reached an optimum performance. Also, Thomas model obtained the value of the linear regression coefficient $\mathrm{R}^{2}$ of 0.5415 . Control activities carried out by veterinarians and 
field health workers are by conducting surveillance of brucellosis. Vaccination and test and slaughter have not been carried out due to limited resources.

\section{Acknowledgment}

Praise be to God Almighty for giving His grace and guidance so that this journal can be completed properly. And we also thank Mrs. Euis Nurul Hidayah ST., MT., Ph.D. because she is the one who always helps and provides direction. As well as colleagues who are good at working together and giving encouragement.

\section{References}

Anggia, D. M., \& Suprapto (2016). Purification of silica in fly ash from power plants in Paiton (PT YTL) with Hydrochloric Acid and Aqua Regia Solvents. Department of Chemistry, Faculty of Mathematics and Natural Sciences, Institut Teknologi Sepuluh November (ITS). Surabaya

Babu , B. V., \& Gupta, S. (2005). Modeling and simulation of fixed bed adsorption column: Effect of velocity variation . India: Department of Chemical Engineering Birla Institute of Technology \& Science Pilani 333031 (Rajasthan).

Benyoucef, S., \& Amrani, M. (2011). Adsorption of phosphate ions onto low cost aleppo pine adsorbent. Desalination, 275(1), 231-236. doi: 10.1016/i.desal.2011.03.004

Kirk, K. E., \& Othmer, D. F, (1981). Encyclopedia of Chemical Technology, 3 edition, Volume 9. New York: The Interscience Encyclopedia, John Willey and Sons, Inc.

Maharani, P.A. (2018). Modeling of phosphate adsorption isotherms in laundry wastes using anion resin. Thesis UPN Environmental Engineering Study Program: Surabaya

Slamet \& Karina K. I. (2017). Utilization of fly ash waste for handling ammonia liquid waste. Journal of Chemistry and Packaging, 5(2), 12-19.

Stevent, D., Dillon, P., Page. D., \& Warne, M. (2011). Assessing environmental risks of laundry detergents in greywater used for irrigation. Journal of Water Reuse and Desalination, 1(2), 61. doi: 10.2166/wrd.2011.027

Tandy, E., et al. (2012). Ability adsorbent waste latex rubber natural against lubricants oils in water, Journal of Engineering Chemistry, 1(2), 1-9.

Voice, T. C. (1997). Activated carbon adsorption. in HM Freeman (ed), Standard Handbook of Hazardous Waste Treatment and Disposal, 2nd edn, McGraw-Hill, New York, pp.6.3-6.21.

Watson, J. S. (1999). Separation methods for waste and environmental applications. New York: Marcel Dekker.

Zhang, W., Lei, D., Han, Y., Haijiang, L., Ziwen, J., Xiaowei, K., Hu, Y., Aimin . L, and Rongshi, C. (2011). Removal of Methylene Blue from Aqueous Solutions by Straw Based Adsorbent in a Fixed-Bed Column . Chemical Engineering Journal 173, No. 2 